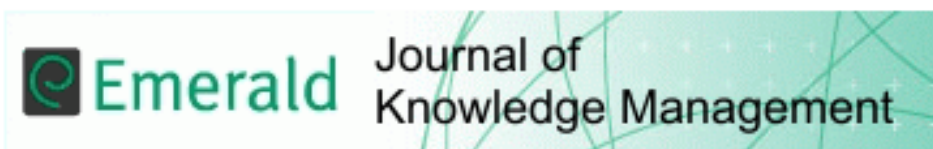

\section{Knowledge Management in Family Business Succession: Current trends and future directions}

\begin{tabular}{|r|l|}
\hline Journal: & Journal of Knowledge Management \\
\hline Manuscript ID & JKM-09-2020-0701.R2 \\
\hline Manuscript Type: & Research Paper \\
\hline Keywords: & $\begin{array}{l}\text { Knowledge management, practice perspective, family business, } \\
\text { succession, transgenerational dynamics, social interactions }\end{array}$ \\
\hline \multicolumn{2}{|l}{} \\
\hline
\end{tabular}

\section{SCHOLARONE \\ Manuscripts}




\title{
Knowledge Management in Family Business Succession: Current Trends and Future Directions
}

\begin{abstract}
Purpose - This article aims at reviewing the literature on knowledge management in family business, addressing the research question: "How is knowledge managed across generations in family business?". We synthesize the literature, highlighting the role of multiple stakeholders who affect knowledge management along the phases of the succession process. Stemming from these findings and embracing a practice-based view, we offer research directions to guide future contributions on knowledge construction in family business. The purpose of this article is not only to conclude the previous research but also to provide insights for future research directions and to provide practical implications.

Methodology - Through a systematic integrative literature review, we collect, map, and analytically examine 63 published peer-reviewed articles related to knowledge management in family business from 39 academic journals. We apply a rigorous approach in order to identify the sample of articles, map descriptive information of the reviewed literature, and map theoretical contributions according to a multi-stakeholder and multi-stage framework.

Findings - The sampled articles are analyzed according to a multi-stakeholder and multi-stage framework inspired by Daspit et al. (2016). We identify critical gaps emerging from our analysis, thus opening the way to future research directions. In particular, we prompt scholars to advance our understanding of family-related knowledge and to clarify the assumptions on knowledge in their research.

Research Implications - We contribute to the debate on knowledge management in family business, by systematizing the current literature. In addition, we embrace a 'knowledge from practice perspective', and offer research directions to guide future contributions on knowledge construction in family business succession and potential areas to further management research investigating the role of family-related knowledge. Practical implications are also provided to benefit family businesses, consultants, and policymakers.

Originality/value - This article provides a systematic integrative literature review of the articles published on knowledge management in family business according to a multistakeholder and multi-stage framework. Moreover, it draws an agenda for future research advancing a 'knowledge from a practice perspective' in the family business literature.
\end{abstract}

Keywords. Knowledge management, practice perspective, family business, succession, transgenerational dynamics, social interactions. 


\section{Introduction}

Knowledge is perhaps one of the most debated, yet loosely defined concepts in management research (Barley et al., 2018). It is widely regarded as a condition for superior performance and competitive advantage (Davenport, 1998; Nahapiet \& Ghoshal, 1998), the foundation to innovative and entrepreneurial endeavors (Easterby-Smith \& Lyles, 2005; Nonaka \& Von Krogh, 2009), and the backbone of businesses in modern society (Nelson, 1982). This warrants research focus on knowledge management within an organization where different actors are involved (Szulanski, 2000; Szulanski et al., 2016). Family businesses, as a unique yet common form of organization, feature a distinctive characteristic - the intertwining family and business systems (Chrisman et al., 2005). Given the different expectations, understandings, and relationships in a family and a business environment (e.g., Hatak \& Roessl, 2015; Pérez-Pérez et al., 2019), research in family business faces a unique and complex challenge in understanding knowledge management, especially between generations during successions (Cabréra-Suárez et al., 2001; Cabréra-Suárez et al., 2018).

In family business literature, knowledge is defined as (family) wisdom (Miller et al., 2016), skills (Cunningham et al., 2016), expertise (Chirico \& Salvato, 2016), and information (Cabréra-Suárez et al., 2001). Scholarly attention to knowledge management in family business succession stresses that the transfer of knowledge between the incumbent and next generation is problematic, yet essential for a successful transition (Cabréra-Suárez et al., 2001; Handler, 1990). It is widely accepted that family business incumbents, regarded as the leader and the key source of firm-specific knowledge holders, need to pass down knowledge to the next generations through mentorship (De Massis, Sieger, et al., 2016; Distelberg \& Schwarz, 2015). The change of key knowledge holder is empirically proven to have negative organisational implications (Massingham, 2008; Zahra \& Filatotchev, 2004) as well as posing a grave challenge for family businesses (Daspit et al., 2016). This trend of literature, however, tends to 
oversee the role of second generations (Woodfield \& Husted, 2017) and other family business employees (Holt et al., 2018), who possess different knowledge that posits potential contributions to business development (Long \& Chrisman, 2014). Another challenge lies in understanding the social aspects of family business succession. Through a business's social life, incumbents develop social capital and networks that are difficult to transfer (Roscoe et al., 2015; Steier, 2001). Although there is evidence that social relationships play a key role in ensuring the continuity of important resources like knowledge during succession (Chirico \& Salvato, 2016; Daspit et al., 2016; De Massis, Sieger, et al., 2016). Interactions among different stakeholders, within and outside the family play a crucial role in better framing and understanding transgenerational knowledge management in family business (Cabrera-Suárez et al., 2018)..

It is, thus, timely to have a review of the literature and integration of the findings on knowledge management in the family business field to sensitize the family business community on the fundamental role of knowledge in a succession process as well as to foster the discussion about relational dynamics within the general management and organizational studies, considering the unique family business social interactions along a succession process. Therefore, with a systematic literature review, we aim to address the following research questions: "How is knowledge managed across generations in family business?", considering especially the role of multiple stakeholders involved in a generational transfer in this type of organization.

We adopt the process by Tranfield et al. (2003) to conduct the systematic literature review and embrace the integrative view by (Elsbach \& van Knippenberg, 2020) not just to offer an overarching view of existing evidence, but also to generate a guiding framework for new primary research and theory development. We thus build on the framework by Daspit et al. (2016), who discussed different levels of social exchange along with the different succession 
phases, in order to offer an analytical discussion of the sampled articles focused on knowledge management in family business. In particular, we advance a multi-stakeholder and multi-stage framework to systematize the reviewed articles and identify promising avenues for future research.

In doing so, this literature review aims at contributing to the debate in the following ways. First, we synergize the current literature on knowledge management in family business, considering the influence of different stakeholders involved across the phases of the succession process. This offers a broader overview of the state-of-the-art on knowledge management during a succession process. Second, leveraging on our systematic view of the current stock of literature, we identify critical gaps and advance future research directions. We show that the scattered findings that emerged from our integrative review open new avenues for designing primary research and set the basis for new theory building. In particular, we identify 'familyrelated knowledge' as an important yet under-researched area. Moreover, we suggest that strictly adhering to the tenets of different theoretical stances becomes fundamental to advance our understanding of knowledge construction in family business literature. We thus burst future research to embrace a 'knowledge from a practice perspective' (for a comprehensive review of different ways to look at knowledge, see Hadjimichael \& Tsoukas, 2019), and to investigate the role of family-related knowledge - both topics that are marginally tackled in the current discussion of knowledge management in family business research. We also contribute to the management literature by understanding knowledge management, looking at family's influences on organizational actors' behaviors.

From this, we structure the rest of the paper as follows. In the next section, we present a multi-stakeholder and multi-stage framework to map the reviewed literature. We then explain our method to systematically identify and analyze the literature, providing all the stages used 
for the review. After having shown the results of our review, we then present our suggestions for future research and implications for practice.

\section{Conceptualizing knowledge management along the succession process}

Knowledge management is used to safeguard the business over time, given its crucial importance during a succession process (e.g., Cabrera-Suárez et al., 2018). In particular, managing knowledge can prove a key success factor for handing over the business to the next generation members. Indeed, this is not a unidirectional process where all knowledge is passed over from the incumbent to their children during succession, but it is a bidirectional process (Woodfield \& Husted, 2017), which involves a complex and time-dependent set of activities and practices to succeed (Le Breton-Miller et al., 2004), as well as the social interactions within and outside the family and the business (Hall \& Nordqvist, 2008; Konopaski et al., 2015).

Knowledge management could manifest in different ways considering the different phases of a succession process and the various types of social interactions that can be considered. To better understand what has been discussed so far and what we still need to investigate in future research, this review relies on an existing framework encompassing the major phases of the succession process and the most important social exchanges that occur along this process (Daspit et al., 2016). On the one hand, the framework considers the main challenges encountered when setting the rules (Phase 1), grooming the successor (Phase 2), and passing the baton (Phase 3); on the other hand, social interactions are considered (i) between incumbents and successors, (ii) within family boundaries, and (iii) across family boundaries. This framework is rooted in the ongoing debate considering the succession as a process characterized by a complex set of actions, events, and mechanisms involved (Le Breton-Miller et al., 2004; Nordqvist et al., 2013), in which all phases are influenced by the type of exchanges occurring within and outside the family, ultimately affecting behavior in the business (Cropanzano \& Mitchell, 2005). Social exchanges have been also broadly discussed 
in the family business context, as they can explain, for instance, the ethical behavior of family firms (e.g., Long \& Mathews, 2011) or the outcome of the relationships between supervisor and employees (e.g., McLarty et al., 2019). Daspit et al. (2016) highlight, in particular, three aspects entailed in social exchanges strongly influencing the succession process, i.e. exchanges of resources, reciprocal obligations and expectations, and relationships where exchanges depend on the development of social networks, reciprocity norms, and shared schemata.

Overall, social interactions can affect the way individuals learn about family business continuity, thanks to the sharing of skills, norms, and values (Konopaski et al., 2015), but little is known about how knowledge is managed along the major phases of the succession process and considering the interactions among different stakeholders imply considering the dynamics between incumbent and successor, within the family, as well as across the family boundaries.

\section{Methodology: A systematic integrative literature review}

In this study, we conduct a systematic, explicit, and reproducible review of the literature on knowledge construction in family business based on an analytic framework, as presented above, to classify existing contributions and to formulate a future research agenda (Light \& Pillemer, 1984). In doing so, we provide an unbiased view of the current "stock" of knowledge in family business (Patriotta, 2020). We adopt Tranfield et al. (2003)'s three-step process to conduct the systematic literature review. The first step is the planning of the review in which the researchers get familiar with the problem domain, frame the research aim, and state research questions (Tranfield et al., 2003). We thus engaged with seminal articles about knowledge in family business (Cabréra-Suárez et al., 2001; Cater III \& Justis, 2009; Chirico, 2008) and developed the research question that we presented above.

The second step consists of the review that includes the selection, extraction, and synthesis of articles on knowledge in family business. Selection needs to focus on relevant articles to support a comprehensive and representative overview of the research domain, while 
extraction and synthesis are directed towards gathering the information from the articles and classify the information with regard to the analytical framework. Hence, after the core information of the articles was extracted, each article was synthesized in accordance with the classification framework. Therefore, each article was read and reflected on the theoretical concepts from the framework presented in the previous section. Finally, according to Tranfield et al. (2003), the third step is the reporting and dissemination of the results, giving room to draw future research directions and practical implications.

This systematic approach thus allows the identifying and mapping process of the existing literature, thus leading us to embrace an integrative view of the literature review, overcoming the sole presentation of the findings in existing studies, but aiming at providing "new insights (theoretical and/or conceptual) that arise from a synthesis and/or critique of extant research" (Elsbach \& van Knippenberg, 2020, p. 3). In the following sections, we explain the exact review process we undertook.

\section{Identifying the sampled articles}

In this stage, we aimed to conduct a comprehensive search in the field by identifying the relevant literature in an inclusive set of keywords. We started with the key terms - "knowledge" and "family business". Guided by family business and knowledge management literature, we expanded the primary key terms "family business" into "family business*" OR "family own*" OR "family firm*" OR "family enterprise*", and "knowledge" into "knowledge" OR "know*how" OR "knowing" OR "Knowledge construct*" OR "knowledge transfer" OR "Knowledge acqui*ition" OR "knowledge management" OR "knowledge shar*" OR "knowledge differentiat*" OR "knowledge integrat"” OR "knowledge process" OR "knowledge speciali*ation" OR "knowledge flow*" OR "knowledge exchange". Our search is conducted following three main steps. 
First, as the nature of family business involves a wide spectrum of fields including both business management and social science, we did not limit our search to business literature. We conducted our search in two highly respected and comprehensive search engines - EBSCO and Web of Science, using the keywords listed above. As both "knowledge" and "family" have a broad application in speech, we limited the search of the keywords in titles and abstracts. In addition, we limited our search to English articles in peer-reviewed journals to ensure the quality of the articles (Campopiano et al., 2017). This yielded 532 results. We then merged the results from the two databases and deleted the duplicate articles, which left us with 457 articles in total. This is done by using Web of Science and EBSCO's exporting function and Endnote's importing and finding duplicate functions.

Second, following Heisig and Kannan (2020), we then read through the titles and abstracts and decided if the articles were relevant to our research question. We considered irrelevant all articles that are not investigating knowledge-related topics or not about family business. For example, if articles refer to the knowledge of an issue or topic, they were excluded. A total of 80 articles was left in this step.

Third, the two authors downloaded the remaining 80 articles and read them independently. Then we compared and discussed the lists of excluded articles that we produced. In this way, we increased rigor in the identifying process. A further 17 articles were excluded after close read for reasons such as the lack of an explicit link to knowledge. We admitted 63 articles as our final sample for this literature review (see Table 1).

\section{Insert Table 1 about here}

We consolidated our final data set in an excel sheet, in which we extracted two types of information from our detailed reading - descriptive and theoretical. For the descriptive elements, we included the articles' basic information (e.g., year, authors, journal, keywords, 
and abstract), other categories that provide insights (e.g., research methods, research regions, theoretical perspective, definitions of knowledge, knowledge type, and knowledge reservoirs). This process helped us to establish the current stock of contributions in the field. For the theoretical elements, we tracked information on the succession phase (i.e. set the rules, grooming the successor, passing the baton) and the type of social interactions where knowledge is constructed (i.e., incumbent-successor, within the family, across the family boundaries). These categories are further illustrated and discussed in the finding and discussion sections.

\section{Mapping descriptive data}

The topic appears as its infant stage, with the earliest in $2001(\mathrm{~N}=1)$ and peaked in $2013(\mathrm{~N}=$ 11). This is reasonable, as knowledge re-emerged as a topic of interest in business and management research in the 1990s (e.g., Grant, 1996; Nonaka, 1994). Despite the recent decrease in the number of publications, the importance of knowledge in family business is not dismissed. For example, Cabréra-Suárez et al. (2018) were invited by Family Business Review to review their 2001 article about knowledge in succession to re-initialize the conversation. This indicates that this field has great potential for future research. The overall trend of this line of research is increasing (See Figure 1).

\section{Insert Figure 1 about here}

With regards to the academic journals, we have articles from 39 journals in total. Despite the efforts to consciously included searches in the broader social science journals, most of the articles are in the business and management discipline. The top four journals (see Table 2) that publish articles related to the topic are Family Business Review ( $\mathrm{N}=10)$, Knowledge Management Research \& Practice $(\mathrm{N}=6)$, Journal of Family Business Strategy $(\mathrm{N}=4)$, and Journal of Knowledge Management $(\mathrm{N}=3)$.

\section{Insert Table 2 about here}


With respect to the research methods of the articles, most of them are empirical (79\%). We identified 13 theoretical / conceptual articles (21\%). Out of the empirical articles, there are three main types of research methods - qualitative (52\%), quantitative (42\%), and mixed methods (6\%). Different from other research topics in family business, which were reported to have more quantitative than qualitative methods (Hair \& Sarstedt, 2014), we found in our sample a balanced mix of qualitative and quantitative methods. (See Table 3)

\section{Insert Table 3 about here}

Organizational studies scholars have been warned of "geographically fragmentation in organizational studies" with the missing attention to certain regions (March, 2005, p. 6). Country differences imply important contextual/institutional elements that contribute to the boundary building and testing of important business theories (e.g., Asian family businesses, see Sharma \& Chua, 2013). Yet, we found research on knowledge management in family business, which is underrepresented in certain regions, leaving potential avenues for future research. This is not to say that these countries are under-researched, but that these regions are probably less mentioned in English articles. We acknowledge that there could be research done in local languages that fell out of our search, but we consider this inclusion could be nonetheless an important feature of the ongoing debate on knowledge management in family business field.

With regards to the distribution of the regions where the research was conducted (see Figure 2), there are a total of 29 different countries identified in the empirical articles. West European $($ Italy $=10 ;$ Spain $=9$, etc. $)$ and North American $(\mathrm{USA}=7)$ countries are the most popular research contexts. We identified East Europe, Mid East, East Asia, and Africa as the underrepresented areas.

Insert Figure 2 about here 
As regards the type of knowledge, we considered whether it is tacit and/or explicit, whether it is business- and/or family-related, and whether it resides within and/or outside the family business.

Tacit and/or explicit knowledge. One of the most accepted ways to understand knowledge is by its tacit and explicit distinction, where tacit knowledge can be understood as knowledge that is hard to express and explicit knowledge is understood as knowledge that can be articulated or codified. It is widely accepted that tacit knowledge is key in family business and that it needs careful management (Cabréra-Suárez et al., 2001). Yet, tacit knowledge is hard to transfer (sticky to its origins) (Szulanski, 1996) and it is hard to be even aware of (Polanyi, 2015).

Business- and/or family-related knowledge. Family businesses present unique types of knowledge due to family involvement, which contributes not only to differentiate family and non-family firms, but also to explain family business heterogeneity. On the one hand, family business needs general business knowledge, such as knowledge about the industry (Le BretonMiller \& Miller, 2015), business/trade-related education (Perez \& Puig, 2004), and business processes (Guo \& Miller, 2010). On the other hand, family involvement brings unique family features to the business, resulting in knowledge from, for example, family values and goals (Kotlar \& De Massis, 2013), or family history (Hjorth \& Dawson, 2016). This type of familyrelated knowledge, undoubtedly, is an important source of competitive advantage in family businesses.

Knowledge within and/or outside the family business. Despite the emphasis on the importance of the incumbents' business-related knowledge (Cabréra-Suárez et al., 2001), other sources of knowledge are either within or outside the family business that attracts scholarly attention. Innovation, for example, requires collaboration with outside companies (Lopes et al., 
2017). Also, external stakeholders, like advisors, could make different contributions to the family business (Nason et al., 2019).

\section{A Multi-stakeholder and Multi-stage Framework of Current Literature}

The systematic analysis of the sampled articles reveals different ways knowledge is managed considering the different stakeholders involved across the different phases of the succession process. In the following sections, we are going to present the contributions of the sampled articles to knowledge construction, considering the three main succession phases presented in the framework above, i.e. setting the rules, grooming the successor, and passing the baton. Table 4 outlines the review of the literature.

\section{Insert Table 4 about here}

\section{Succession phase 1. Setting the rules}

In this section, we include 19 articles that focus on the way knowledge is constructed in the preliminary stage of the succession process, i.e. to set up the ground rules to plan the transition from generation to generation.

Between incumbent and successor. When considering the interaction between incumbent and successor, scholars have identified a few dimensions that can determine how knowledge is managed. A key aspect that emerges is the extent to which incumbents ensure that successors refrain from opportunistic behavior, thus suggesting that trust plays a relevant role to construct knowledge when planning the succession: incumbents, indeed, need to build relational competence, i.e. the ability of a party to initiate and maintain relationships, to ensure effective knowledge transfer (Hatak \& Roessl, 2015). Indeed, the incumbent is responsible for both tacit and explicit knowledge in processes of knowledge integration, e.g. through family meetings that help translate tacit into explicit knowledge, in family firms with high transgenerational control intention (Carr \& Ring, 2017). Related to this, stemming from a 
transaction cost approach, planning a succession depends on the idiosyncratic knowledge of how to run the business and access network relations within the business environment, as well as contingent on the institutional context, e.g. subject to inheritance laws (Bjuggren \& Sund, 2002). Moreover, studying a long-lived case study in Colombia, both private knowledge of family members and specific knowledge about the business are fundamental to set the ground for family business continuity, despite the low human capital of successors who led the family firm over time (González Ferrero et al., 2010).

Within the family boundary. Including other family members, a study highlights that leadership styles determine the rules of succession processes, although these are strongly dependent on contextual contingencies, e.g. distinguishing among baby boomers, generation X, generation Y (Klenke, 2018). Similarly, it emerges that a more participative leadership style encourages more open knowledge sharing, especially in small family businesses (Cunningham et al., 2016, 2017). Instead, in a sample of Taiwanese family firms, paternalistic leadership emerges as the dominant approach to transfer knowledge (Lin, 2013). From a different perspective, what is important in planning succession is to make the sources of knowledge explicit, by establishing knowledge management systems that allow to transfer not just individual knowledge, but also transfer know-what, know-why, know-how, know-who, and know-where, with a focus on familiness (Nicholson \& Rao-Graham, 2016), namely the bundle of resources and capabilities that are available in the business thanks to the family (Habbershon \& Williams, 1999).

Across the family boundary. Considering the exchanges across the boundaries of the family, first, embracing the concept of intellectual capital, successors might need to manage three types of knowledge, namely structural capital, social capital, and human capital: it is important to grasp, respectively, to what extent knowledge about processes is formalized, what type of knowledge about branding, customer loyalty or reputation is available, as well as the 
competences and abilities of employees on which especially small firms rely on (Bracci \& Vagnoni, 2011). Similarly, being able to identify and measure intellectual capital dimensions, e.g. capabilities and knowledge of both family and non-family members, is fundamental to build a competitive advantage for family businesses (Claver-Cortes et al., 2013; Claver-Cortes et al., 2015). This "knowledge related human capital" depends on several aspects - such as social interactions in the family business, motivation, commitment, psychological ownership, as well as education and experiences within and outside the business - thus explaining the knowledge accumulation process that characterizes family firms over time (Chirico, 2008). Moreover, establishing knowledge management systems to integrate the knowledge of new employees with retiring and retired ones (Doring \& Witt, 2020), as well as setting up management accounting systems (Giovannoni et al., 2011) can affect the transfer of knowledge across generations and between the owner family, the management team and the workforce, thus supporting a successful succession process. Furthermore, in response to strategic renewal goals, family businesses might show different behaviors in terms of establishing knowledge management practices, thus being proactive, adaptive, rather than rigid family firms (PérezPérez et al., 2019). Also cultural aspects, in particular family wisdom, shape familiar relationships in the business and determine how knowledge is transferred (Wasim et al., 2018). Outside the family and the business, sharing knowledge among external advisors improve the quality of the service offered by each advisor, which can support the set-up of the activities for the future of the business (Su \& Dou, 2013).

Interestingly, in this section, it emerges that a few core practices are planned or established to construct knowledge to ensure a trustful relationship once the successor joins the family business. Moreover, in some papers, the attention is directed towards the establishment of knowledge management systems or management accounting systems to facilitate knowledge management to prepare for the succession process. 


\section{Succession phase 2. Grooming the successor}

Grooming the successor is the most crucial phase of the succession process when knowledge is shared, transferred, acquired, and created, as 17 studies discuss the importance of nurturing and training next generation members.

Between incumbent and successor. Looking at the social interactions between incumbent and successor, first, several articles discuss the main drivers to transfer knowledge to the successor. For example, it is important that family members value commitment and psychological ownership towards the business, appreciate family relationships working in the business, as well as engaging in training courses and gaining experience outside the business or from non-family members (Chirico, 2008). In addition, both intra- and inter-generational dynamics, trust and predecessor involvement in the successor training, as well as business culture and linkages with Family Business Associations are significant antecedents of effective knowledge transfer (Martínez et al., 2013).

In particular hands-on knowledge is regarded by employees as necessary to ensure that next generation members acquire knowledge in small family businesses (Cater III \& Justis, 2009). This is also facilitated when familiness and high levels of trust positively affect power relationships among incumbent and successor (Muskat \& Zehrer, 2017). These aspects, moreover, resonate with the idea that knowledge is created thanks to the bidirectional exchange between incumbent and successor, who have different knowledge bases, i.e. sources of knowledge and extent to which they have tacit versus explicit knowledge (Woodfield \& Husted, 2017). It cannot be overlooked also the nurturing style in the social interaction between incumbent and successor, who can engage in "learning alongside" versus "learning apart" thus granting different levels of autonomy in sharing both tacit knowledge - about internal operations, client management, and competition - and institutional knowledge, which includes the experiences and understanding of institutional framework, rules, norms, and values (X. T. 
Wang \& Jiang, 2018). On top, transferring moral values and competence values, more than cognitive heuristics, ensures the imprinting of entrepreneurial practices in nurturing successors (Dou et al., 2020). Interestingly, in nurturing the successor, the focus on the process of knowledge transfer is relevant to build a competitive advantage if the successor learns how to use that knowledge (Cabréra-Suárez et al., 2001).

Within the family boundary. This debate has been also furthered by insights on knowledge construction looking at social interactions within the family. In a follow-up study, Cabréra-Suárez et al. (2018) discuss the role of a combined effort of a wide range of members to leverage familiness to construct knowledge. In addition, extending the $4 \mathrm{I}$ model that stems from organizational learning theory, family members are "knowledge supervisors" who enable information intuiting, interpreting, integrating, and institutionalizing, thus transferring knowledge to foster strategic change in the family business (Lionzo \& Rossignoli, 2013). Nevertheless, while family ties foster both formal and informal knowledge sharing, jealousy and rivalry can dampen it, although this is lessened by having multiple generations involved and a high number of family members in the TMT (Zahra et al., 2007). In addition, taking advantage of the unique potential of family ties, leading to generalized social exchanges, makes family members engage in effective tacit knowledge management, in terms of knowledge transfer, assimilation, and protection (Jaskiewicz et al., 2013). Similarly, a study about mentoring and coaching suggests that tacit knowledge, which is intrinsic in family relationships, rather than explicit knowledge, can explain performance advantages of family firms (Utrilla \& Torraleja, 2013).

Across the family boundary. More insights are, instead, offered to understand the phenomenon of knowledge construction during the phase of grooming the successor, looking at social interactions across the family boundaries. A focus on the socialization of next generation members suggests that both bonding and bridging social capital determine the 
collective knowledge structure of the owning family, changing reference points in the family business and, in turn, strategic decision-making (Nason et al., 2019). To nurture successors, leveraging social interactions with actors outside the family, knowledge to share encompasses experiential knowledge assets, i.e. know-how, and knowledge from serving multiple roles, e.g. managers and owners (Pipatanantakurn \& Ractham, 2016). Training successors both inside and outside the business requires involving next generation members in strategic planning activities (Mazzola et al., 2008). Joining this conversation on training successors beyond the boundaries of the family business, from a socio-historical perspective, also institutional dimensions have to be accounted as, over time, affect training practices in a specific context (Perez \& Puig, 2004).

Overall, it is relevant to this phase of the succession process to establish practices aimed at training and mentoring successors, for example involving them in strategic planning, granting them autonomy to acquire knowledge from the incumbents, or transferring them both moral and competence values.

\section{Succession phase 3. Passing the baton}

When the succession process is at the end and successors are ready to take the lead of the business, there are several issues about knowledge management that have implications for the business, as underlined in the following 27 articles.

Between incumbent and successor. Considering the social interaction between incumbent and successor, there is evidence that when the senior generation is the source of knowledge, the business persists in its strategies, while, when the source of knowledge is the next generation, new approaches are introduced, with potential for innovation activities and outcomes (Woodfield \& Husted, 2019). Further, the drivers of absorptive capacity, i.e. the ability of the business to acquire and integrate knowledge from external sources, can be identified in the low motivation gap, juxtaposed by a high implementation gap, typical of the 
moment in which incumbents pass the baton to successors, suggesting that, although potential absorptive capacity improves, realized absorptive capacity actually deteriorates (Kotlar et al., 2020). From a different angle, a focus on the opportunity to embrace innovativeness for the future of the family business, it is important that successors gain experience externally in other businesses to finalize the takeover of the inherited business (Letonja \& Duh, 2016). Similar findings emerge in a study on sustainable innovation, considering however that successors' willingness to take over can be constrained by the incumbents' approval (Y. Z. Wang et al., 2019).

Within the family boundary. Extending the analysis to social interactions within the family, it emerges that such interactions are relevant for knowledge integration, a dynamic capability aimed at recombining knowledge, to sustain the competitive advantage of family businesses (Chirico \& Salvato, 2008). Moreover, focusing on knowledge sharing in different world regions, it emerges that previous experiences, accumulation of explicit knowledge, and its conversion into tacit knowledge enable value creation across generations (Duarte Alonso \& Kok, 2020). Also, generational involvement affects value creation over time, as Memili et al. (2015)'s research suggests that family-owned businesses with a first generation's majority have higher value appropriation abilities compared to non-family firms, while family ownership with second or later generation's majority exhibits lower levels of value creation capabilities.

From a different angle, knowledge sharing enables psychological ownership to make family businesses entrepreneurially oriented, and this is dependent on the generation in control, generational involvement, and family involvement in the TMT (Pittino et al., 2018). In a similar vein, it emerges that the strengthening effect of family influence on the role of knowledge transfer in explaining entrepreneurial orientation and performance (Martínez et al., 2016). Furthermore, the difference between family and non-family firms in finding new entrepreneurial opportunities lies in the differences in knowledge stocks, knowledge 
combination, and the long-term orientation of family managers (Patel \& Fiet, 2011). Nonetheless, a study also highlights that family involvement can exert a negative impact on the effect of internal, collaborative, and external knowledge sources on innovation performance (Serrano-Bedia et al., 2016). Along this line, in a study on small family businesses, Yew and Gomez (2014) find that these organizations need to codify existing tacit knowledge to innovate and thrive.

In addition, internalization of knowledge among family members is essential to make family social capital and family relationship conflict affect product development in family business (Chirico \& Salvato, 2016). Moreover, having family members on the board of directors allows conveying family-specific knowledge, which is helpful to determine board compensation (Wu, 2013).

Across the family boundary. Spanning across the boundaries of the family, absorptive capacity requires leveraging knowledge transfers from external sources - such as counseling, publications, as well as training and education programs - to make family firms thrive over time (Duh \& Belak, 2008). This, indeed, supports especially small family firms to sustain performance by innovating products, processes, and the organization via knowledge acquisition and assimilation (Chaudhary \& Batra, 2018). This insight is also reflected in acknowledging how small and medium-sized family firms rely on external knowledge to spur innovation, which is inherent in an industry's technological opportunities and interorganizational collaboration (Kallmuenzer \& Scholl-Grissemann, 2017). Networking is also accounted as a relevant driver supporting adaptation and change thanks to the firm's engagement in tacit knowledge operationalization, explicit knowledge acquisition, and knowledge sharing (Duarte Alonso et al., 2019). Similarly, social capital is accounted as significant to foster the family business's capacity for knowledge transfer and intellectual capital formation, in turn affecting innovation and strategic differentiation ( $\mathrm{Su} \&$ Carney, 
2013). There is evidence that family businesses, from a historical perspective, manage to become multinational organizations thanks to a continuous process of knowledge accumulation, passing the firm's legacy across generations via building networks, internationalizing and overcoming historical critical events, such as economic crises, wars, and market disruptions (Fernández Moya, 2010). Similarly, discussed study shows how absorptive capacity leverages on existing accumulated knowledge and experiences to enable the family business to acquire new knowledge and cope with disruptions and crises, as investigated in the case of a family-owned airline (Boyd \& Hollensen, 2012).

It is important that firms build knowledge management process capabilities to foster organizational flexibility (Bamel \& Bamel, 2018). And besides that, the presence of non-family members, on the one hand, and familiness on the other hand, have different effects on knowledge acquisition and assimilation (potential absorptive capacity), and knowledge transformation and exploitation (realized absorptive capacity) activities, thus affecting innovation (Daspit et al., 2019). Furthermore, emblematic the case of a family business that has managed to integrate external knowledge to embrace open innovation, by relying on absorptive capacity, in order to implement sustainable innovations and thus contribute to the sustainability agenda (Lopes et al., 2017). In discussing the specific challenges in knowledge acquisition and transfer, Casprini et al. (2017) show how a family business has developed, through its open innovation processes, two idiosyncratic capabilities, namely imprinting and fraternization.

As regards the use of market and technological knowledge, it is knowledge sharing, more than the availability of these types of knowledge, that allows family firms to leverage this external knowledge to increase their performance (Alberti \& Pizzurno, 2013). Relying on a single case study, Pogutz and Winn (2016) discuss how family firms that develop deep knowledge about sustainability can increase their innovative capability and, simultaneously, 
reduce their environmental impact. Finally, transferring and integrating specific knowledge about finance and a family firm's capital structure, along with positive experience with debt suppliers and owner-managers' financial attitudes toward debt, is deemed fundamental to increase debt financing (Koropp et al., 2013).

In sum, accumulating experience outside the family business emerges as a crucial practice to construct knowledge in the ultimate phase of the succession process. Considering the multi-stakeholder and multi-stage framework used above (see Table 4), we found some popular topics peculiar to each phase. Among the most investigated, we identified (i) the factors enabling the set-up of the succession, e.g. establishing a knowledge management system; (ii) training, mentoring, coaching of potential successors, especially during the phase of grooming the successor; and (iii) acquiring knowledge that influences firm outcomes such as innovation, when passing the baton to the successor. We identified that, in particular, more discussions in phase 1 setting the rules within family boundray would be especially needed in the current literature to enrich our understanding of knowledge management in family business succession.

\section{An Agenda for future research}

We addressed our research question "how is knowledge managed across generations in family business?" in the multi-stakeholder and multi-stage framework above. In this section, based on a solid understanding of the current stock on research on knowledge management in family business field, we advance the field by focusing on three main areas - future research directions, contributions to literature, and practical implications.

\section{Future Research Directions}

Knowledge is undoubtedly a vital resource for generational activities in family businesses, in particular during succession processes (e.g., Cabréra-Suárez et al., 2018; Y. Z. Wang et al., 2019; Woodfield \& Husted, 2017), as well as one of the key sources of competitive advantage 
for family businesses (Cabréra-Suárez et al., 2001; Chirico \& Salvato, 2008; Zahra et al., 2007), which contribute to family business's idiosyncrasies (Bjuggren \& Sund, 2002). Research finds that knowledge between generations has an impact on important firm outcomes like innovation (e.g., De Massis, Frattini, et al., 2016; Yew \& Gomez, 2014), crisis management (e.g., Boyd \& Hollensen, 2012), and sustainability (e.g., Pogutz \& Winn, 2016; Y. Z. Wang et al., 2019), to name a few. Despite the current research, we advance two main areas to advance this line of research - knowledge from a practice perspective and family-related knowledge.

Knowledge from a Practice Perspective. We notice from our analysis that different authors apply different theoretical assumptions in understanding knowledge, which however are left unexplained or un-clarified. This makes it difficult both theoretically and practically to advance the field of knowledge in family business research.

Theoretically, there is an observable monopoly of knowledge-based view, rooted especially in the work by Nonaka (1994), in knowledge management research in family businesses. We found that even if some researchers are vague on their epistemology of knowledge, it could be inferred from their work that they emphasize the conversion and transfer of knowledge. Knowledge in this view follows the Cartesian philosophy and the traditional definition of "justified true belief" (Nonaka, 1994, p. 15), with a locus on the individual. As a result, Nonaka's (1994) SEIC $^{1}$ model is the most widely cited. For example, by combining Handler's (1990) succession process with Nonaka's SEIC model to show the knowledge progress in the succession process, Pipatanantakurn and Ractham (2016) look for "tools to help owners replicate and create new sets of information for their successors" in their research. This is theoretically problematic. Firstly, this model neglects the discussion on social dimensions

\footnotetext{
${ }^{1}$ Tacit knowledge and explicit knowledge transfer and convert model - S(ocialization) - E(xternalization) I(nternalization) - C(ombination)
} 
(Nonaka \& Von Krogh, 2009). Therefore, it overlooks discussion on social interaction dynamics. Secondly, this monopoly also hinders the development of the topic, as there are new ways to understand knowledge, which have opened many conversations in organizational research. These different views lead to interesting outcomes and advance the development of the knowledge management field (for detailed discussions, see Cook \& Brown, 1999; Hadjimichael \& Tsoukas, 2019; Tsoukas \& Vladimirou, 2001).

In order to provide a linkage between research on knowledge in family business field with organizational research, we provide a preview of the latest discussion on looking at 'knowledge from a practice perspective'. According to Hadjimichael and Tsoukas (2019), from this practice perspective, knowledge is embedded in practices. This leads attention to the takenfor-granted daily activities in an organization - "dynamics, relations, and enactment" (p.1240), which provides timely understanding to contemporary organizing (Feldman \& Orlikowski, 2011). Therefore, knowledge can be seen not as a "static entity or stable disposition, but rather an ongoing and dynamic production that is recurrently enacted as actors engage the world in practice" (Feldman \& Orlikowski, 2011, p. 1243).

Taking this perspective, knowledge comes in a constructivist manner that involves the work of a combined effort of a wide range of stakeholders who have both temporal (e.g., childhood) and spatial (e.g., in school) dimensions (Nason et al., 2019). Considering learning as situated in different situations is also found to be highly relevant in entrepreneurial learning in family business between generations (Hamilton, 2011). Giovannoni et al. (2011) find that family businesses have knowledge embedded in accounting practices, which are vital for business survival.

We observe in our literature review that this perspective is much less discussed and used. Yet, due to the change of epistemological assumptions that knowledge is embedded in practices rather than individuals, and its focus on social dynamics, this perspective can provide 
insights to advance knowledge management literature within the debate on succession processes in family business research. Accordingly, we suggest that future research should engage in re-thinking the most appropriate research designs to collect data about dynamics, relations, and enactment and investigate research questions that stem from a practice perspective and ensure a fit between theory and empirics. For example, the change of "basic unit of analysis from individuals and their actions to practices and their relationships" (Nicolini, 2011, p. 603). Haag (2012) proposed a 'methodological bricolage' (p. 68) combining a few sets of data sources to overcome the difficulties of data required for practice studies. Therefore, we call scholars to seek for more innovative ways to collect and analyze qualitative data to investigate knowledge management practices, for example, the use of ethnographic studies to understand network and relationships within and across the family and business boundaries from a practice-based perspective, thus addressing those types of research questions (for the recent development of qualitative research in family business, see De Massis \& Kammerlander, 2020).

Family-related knowledge. It is well known that family involvement in family business brings in unique features to this field (Chua et al., 1999). Family routines, for example, are theorized to perform an important role in influencing next generation's future engagement in family businesses (Reay, 2019). Recently, family science, which looks at the heterogeneity of families, has also been raised to advance the family business field (Combs et al., 2020; Jaskiewicz \& Dyer, 2017; Neubaum, 2018).

We propose future research directions encompassing family-related knowledge to advance knowledge management in family business succession. In particular, from a 'knowledge from practice perspective', we call for more studies in practices that happened in the family domain. We propose that upon closer inspection, family becomes the site where purposeful and un-purposeful activities happen (Schatzki, 1996), in which participants 
(successors) construct their own meaning, identity, and agency (Nicolini, 2011). Activities in families, including the mundane activities (e.g., chaos), that insert influence on the successors, are more than what meets the researchers' eye (Morgan, 1996). Therefore, there are potential fruitful outcomes to explore knowledge management through their practices in the families' daily activities.

In addition, this would also enable investigation of temporal considerations (Le BretonMiller \& Miller, 2014; Sharma et al., 2014) in succession research as practices in families not only extend the research to practices in the family domain but also stretch the consideration of 'when succession starts'. Through their informal participation in the family sphere, potential successors get involved in the family business long before they actually join the family business (Cabréra-Suárez et al., 2018; Cater III \& Justis, 2009; Handler, 1992; Hatak \& Roessl, 2015; McMullen \& Warnick, 2015), and their impact could exceed the business boundary to institutional effects (Cappelen \& Pedersen, 2020; Konopaski et al., 2015). Yet, we know little about the influences of such practices, which can open interesting discussions on topics like successor engagement and successor training, to name a few. In particular, this would provide important insights for succession phase 1 - Setting the rules. For example, scholars can study how practices in the family domain introduce important elements of family-related knowledge to the successor, including family values, family traditions, and family histories. How do family values and norms evolve in the accumulation and integration of knowledge, thus affecting goal setting (Kotlar \& De Massis, 2013) and reference points (Nason et al., 2019)?

Lastly, family practices are not static, but continuously change. Scholars have a greater opportunity to build on family theories (Jaskiewicz et al., 2017) and contribute to better explain how family-related knowledge is passed and integrated over time. Life course theory and family developmental theory, for instance, stress the importance of transitions, which could be relevant triggers for change in knowledge management and significantly affect knowledge 
creation (Howard E Aldrich \& Cliff, 2003). The birth of a new baby, marriage, death, and divorce are all events that can change family dynamics and trigger changes in daily practices, including setting new goals, raising expectations, and new wishes for the family and the business. Yet, also drastic changes in the family business, such as a failure (e.g., liquidation and bankruptcy) can pose serious challenges to the family, which can leverage on its knwoeldge to make a new plan for the family and how to make a living (File \& Prince, 1996; Miller et al., 2003). Considerations about succession as a planned or sudden phenomenon require more attention (e.g., Steier, 2001), as the unintended consequences of a sudden succession can provide fertile ground to study practices to enable the knowledge management process. All the changes in family practices, therefore, make knowledge creation a fundamental aspect. We prompt future research to integrate these theories and look at knowledge from new and novel perspectives in management as well as social science fields. In doing so, we would also suggest embracing alternative research designs, which consider the family as the object of analysis, focusing on the household composition or characteristics of the family members, such as gender, ethnicity, age, and so forth (H. E. Aldrich et al., 2021; Winter et al., 1998).

\section{Contributions to Management Research}

Due to the involvement of family in business management (Chua et al., 1999), family business literature can contribute to the knowledge management research, by providing insights on influences and perspectives from a family-related topic on understanding individual behaviors. In our review, we find ample research emphasizing the importance of family or family units (Carr \& Ring, 2017; Zahra et al., 2007). Broadly speaking, family is the basic unit of society; families, in many aspects, "influence entrepreneurs, employees, managers, and their organizations" (Jaskiewicz et al., 2017, p. 309). Families, especially through family practices, embed knowledge like family values, family traditions, and family history. Family practices like story-telling about families pass on transgenerational entrepreneurship and resilience 
(Jaskiewicz et al., 2015). In our review, for example, Dou et al. (2020) find that values (as one element of knowledge) rather than heuristics are passed between the two generations in new entrepreneurial settings. Su and Dou (2013) suggest that knowledge of family vision among advisors has a relevant impact on the quality of advisors' service. Notwithstanding these initial efforts, we reconcile with Jaskiewicz et al. (2017) and call for future research in management to look at organization actors' families to understand the potential impact of knowledge coming from actors' families of origin on important behavior variance including resilience, entrepreneurial orientation, and, potentially, teamwork.

\section{Practical implications}

We believe that, although a literature review mainly aims at systematizing existing knowledge about a topic and offering avenues for future research, better understanding the status quo about knowledge management in family business provides several implications for family businesses, consultants, and policymakers.

First, family business owners and managers can get a glimpse of the core dimensions that represent opportunities as well as hurdles in managing knowledge. In other terms, we invite family businesses to constantly reflect on their practices at work and at home, considering their stage in the succession process and taking into account the stakeholder involved. For example, family business owners and managers can consider establishing a knowledge management system while planning a succession, as well as creating some best practices to train and groom the successor, but also consider the role of managing knowledge to effectively run the business as there are significant effects on innovation, entrepreneurial endeavors, sustainability and so on.

Second, there is ample room for family business consultants and therapists to reflect on the actual needs of their clients, considering the core, yet sometimes indistinct, role of knowledge. Understanding how knowledge flows, who is keeping knowledge, and what might 
be the difficulties in mobilizing it and make it explicit, could help their work in supporting family businesses through their struggles. For example, consultants might consider the insights from this study to design a succession plan for businesses, which might consider factors affecting knowledge management, including for instance commitment, psychological ownership, leadership styles, just to name a few (for a comprehensive picture, see Table 4). Moreover, this literature review can inform advisors who could learn about the mechanisms to transfer knowledge and, at the same time, train and nurture the entrepreneurial skills of next generation members.

Third, policymakers might consider the importance of knowledge accumulation and integration to create value in businesses that, in most countries, represent the backbone of economies (Oxford Economics, 2018). Installing policies that allow firms to interact, learn and acquire new capabilities from a dynamic and munificent environment can be key to make family firms survive, grow, and thrive across generational transitions. Knowledge construction can develop many opportunities to innovate that, especially looking at the digitization revolution, seem otherwise unreachable for many family firms. It would be a great chance for policymakers and family business associations to foster a practice perspective on knowledge and encourage training and learning opportunities dedicated to family and non-family managers.

\section{Conclusions}

Knowledge is undoubtedly a vital resource for businesses (Barley et al., 2018) and a key source of competitive advantage (Spender \& Grant, 1996). There are many different ways to frame knowledge and many of these ways are under heated discussion and rapid development (for detailed discussions, see Cook \& Brown, 1999; Hadjimichael \& Tsoukas, 2019; Tsoukas \& Vladimirou, 2001). 
This literature review provides a systematic overview of the studies on knowledge construction across generations in family business. According to a multi-stakeholder and multistage knowledge-succession process framework, we systematically analyze the reviewed literature, offering a broader picture of the complexity of delving into knowledge management in business that deals with two different systems, the family and the business. Our analysis highlights the core items that have been discussed and identifies the key practices to construct knowledge in each phase of the succession process. This, therefore, gives a comprehensive picture of the findings of different studies and sheds light on the complicating factors of having the family involved in the business when it comes to managing and creating knowledge. We identified (i) the factors enabling the set-up of the succession (phase 1), (ii) training, mentoring, coaching of potential successors (phase 2), and (iii) acquiring knowledge that influences firm outcomes such as innovation (phase 3) are the three most investigated areas. From our framework, we concluded that, in particular, more discussions for themes and characteristics within family boundary during phase 1 would enrich our understanding of knowledge management in family business succession process.

This enables us to call for future research using a 'knowledge from a practice perspective', which challenges the current assumptions of knowledge management and the role of family-related knowledge, as well as "family-related knowledge". Moreover, our review also benefits management research by highlighting the impact of family involvement in individual behaviors. We have, in addition, pointed out three practical implications for family business owners, consultants, and policy-makers respectively.

We hope these insights will be seriously taken in designing ad-hoc solutions for these organizations. We believe this work has only shown the surface of a deep and underinvestigated realm, which requires novel approaches to completely unfold, helping us understand knowledge management in family business succession process. 


\section{References}

Alberti, F. G., \& Pizzurno, E. (2013). Technology, innovation and performance in family firms. International Journal of Entrepreneurship \& Innovation Management, 17(1), 142-161.

Aldrich, H. E., Brumana, M., Campopiano, G., \& Minola, T. (2021). Embedded but not asleep: entrepreneurship and family business research in the 21st century. Journal of Family Business Strategy, 100390.

Aldrich, H. E., \& Cliff, J. E. (2003). The pervasive effects of family on entrepreneurship: Toward a family embeddedness perspective. Journal of Business Venturing, 18(5), 573-596.

Bamel, U. K., \& Bamel, N. (2018). Organizational resources, KM process capability and strategic flexibility: a dynamic resource-capability perspective. Journal of Knowledge Management, 22(7), 1555-1572.

Barley, W. C., Treem, J. W., \& Kuhn, T. (2018). Valuing Multiple Trajectories of Knowledge: A Critical Review and Agenda for Knowledge Management Research. Academy of Management Annals 12(1), 278-317.

Bjuggren, P. O., \& Sund, L. G. (2002). A transaction cost rationale for transition of the firm within the family. Small Business Economics, 19(2), 123-133.

Boyd, B., \& Hollensen, S. (2012). Strategic management of a family-owned airline: Analysing the absorptive capacity of Cimber Sterling Group A/S. Journal of Family Business Strategy, 3(2), 70-78.

Bracci, E., \& Vagnoni, E. (2011). Understanding Small Family Business Succession in a Knowledge Management Perspective. IUP Journal of Knowledge Management, 9(1), 7-36.

Cabréra-Suárez, M. K., De Saá-Pérez, P., \& García-Almeida, D. (2001). The succession process from a resource-and knowledge-based view of the family firm. Family Business Review, 14(1), 37-48.

Cabréra-Suárez, M. K., Garcia-Almeida, D. J., \& De Saa-Perez, P. (2018). A Dynamic Network Model of the Successor's Knowledge Construction From the Resource- and Knowledge-Based View of the Family Firm. Family Business Review, 31(2), 178-197.

Campopiano, G., De Massis, A., Rinaldi, F. R., \& Sciascia, S. (2017). Women's involvement in family firms: Progress and challenges for future research. Journal of Family Business Strategy, 8(4), 200-212.

Cappelen, S. M., \& Pedersen, J. S. (2020). Inventing Culinary Heritage through Strategic Historical Ambiguity. Organization Studies, 42(2), 223-243.

Carr, J. C., \& Ring, J. K. (2017). Family firm knowledge integration and noneconomic value creation. Journal of Managerial Issues, 29(1), 30-56.

Casprini, E., De Massis, A., Di Minin, A., Frattini, F., \& Piccaluga, A. (2017). How family firms execute open innovation strategies: The Loccioni case. Journal of Knowledge Management, 21(6), 1459-1485.

Cater III, J. J., \& Justis, R. T. (2009). The Development of Successors From Followers to Leaders in Small Family Firms: An Exploratory Study. Family Business Review, 22(2), 109-124.

Chaudhary, S., \& Batra, S. (2018). Absorptive capacity and small family firm performance: exploring the mediation processes. Journal of Knowledge Management, 22(6), 12011216.

Chirico, F. (2008). Knowledge accumulation in family firms - Evidence from four case studies. International Small Business Journal, 26(4), 433-462. 
Chirico, F., \& Salvato, C. (2008). Knowledge integration and dynamic organizational adaptation in family firms. Family Business Review, 21(2), 169-181.

Chirico, F., \& Salvato, C. (2016). Knowledge Internalization and Product Development in Family Firms: When Relational and Affective Factors Matter. Entrepreneurship Theory and Practice, 40(1), 201-229.

Chrisman, J. J., Chua, J. H., \& Steier, L. (2005). Sources and consequences of distinctive familiness: An introduction. Entrepreneurship Theory and Practice, 29(3), 237-247.

Chua, J. H., Chrisman, J. J., \& Sharma, P. (1999). Defining the Family Business by Behavior. Entrepreneurship: Theory and Practice, 23(4), 19-39.

Claver-Cortes, E., Molina-Manchon, H., \& Zaragoza-Saez, P. (2013). Intellectual capital model for family firms. Knowledge Management Research \& Practice, 11(2), $184-$ 195.

Claver-Cortes, E., Zaragoza-Saez, P. C., Molina-Manchon, H., \& Ubeda-Garcia, M. (2015). Intellectual capital in family firms: human capital identification and measurement. Journal of Intellectual Capital, 16(1), 199-223.

Combs, J. G., Shanine, K. K., Burrows, S., Allen, J. S., \& Pounds, T. W. (2020). What do we know about business families? Setting the stage for leveraging family science theories. Family Business Review, 33(1), 38-63.

Cook, S. D., \& Brown, J. S. (1999). Bridging Epistemologies: The Generative Dance Between Organizational Knowledge and Organizational Knowing. Organization science, 10(4), 381-400.

Cropanzano, R., \& Mitchell, M. S. (2005). Social exchange theory: An interdisciplinary review. Journal of Management, 31(6), 874-900.

Cunningham, J., Seaman, C., \& McGuire, D. (2016). Knowledge sharing in small family firms: A leadership perspective. Journal of Family Business Strategy, 7(1), 34-46.

Cunningham, J., Seaman, C., \& McGuire, D. (2017). Perceptions of Knowledge Sharing Among Small Family Firm Leaders: A Structural Equation Model. Family Business Review, 30(2), 160-181.

Daspit, J. J., Holt, D. T., Chrisman, J. J., \& Long, R. G. (2016). Examining Family Firm Succession From a Social Exchange Perspective: A Multiphase, Multistakeholder Review. Family Business Review, 29(1), 44-64.

Daspit, J. J., Long, R. G., \& Pearson, A. W. (2019). How familiness affects innovation outcomes via absorptive capacity: A dynamic capability perspective of the family firm. Journal of Family Business Strategy, 10(2), 133-143.

Davenport, T. H. (1998). Working knowledge: how organizations manage what they know. Boston, Mass: Boston, Mass : Harvard Business School Press.

De Massis, A., Frattini, F., Kotlar, J., Petruzzelli, A. M., \& Wright, M. (2016). Innovation through tradition: Lessons from innovative family businesses and directions for future research. Academy of Management Perspectives, 30(1), 93-116.

De Massis, A., \& Kammerlander, N. (2020). Handbook of qualitative research methods for family business: Edward Elgar Publishing.

De Massis, A., Sieger, P., Chua, J. H., \& Vismara, S. (2016). Incumbents' Attitude Toward Intrafamily Succession. Family Business Review, 29(3), 278-300.

Distelberg, B. J., \& Schwarz, T. V. (2015). Mentoring Across Family-Owned Businesses. Family Business Review, 28(3), 193-210.

Doring, H., \& Witt, P. (2020). Knowledge management in family businesses-Empirical evidence from Germany. Knowledge Management Research \& Practice, 18(2), 175187. 
Dou, J. S., Su, E. M., Li, S. X., \& Holt, D. T. (2020). Transgenerational entrepreneurship in entrepreneurial families: what is explicitly learned and what is successfully transferred? Entrepreneurship and Regional Development, 1-15.

Duarte Alonso, A., \& Kok, S. (2020). Knowledge and the family firm through generations: a knowledge-based approach in various geographic contexts. Knowledge Management Research \& Practice, 1-14.

Duarte Alonso, A., Kok, S., \& O'Shea, M. (2019). The family business, adversity and change: A dynamic capabilities and knowledge-based approach. Journal of General Management, 44(2), 96-109.

Duh, M., \& Belak, J. (2008). Special knowledge needs of family enterprises in transition economies: experiences from Slovenia. Knowledge Management Research \& Practice, 6(3), 187-198.

Easterby-Smith, M., \& Lyles, M. A. (2005). The Blackwell handbook of organizational learning and knowledge management. Oxford : Blackwell: Malden, Mass.

Elsbach, K. D., \& van Knippenberg, D. (2020). Creating High-Impact Literature Reviews: An Argument for 'Integrative Reviews'. Journal of Management Studies, 57(6), 1277-1289.

Feldman, M. S., \& Orlikowski, W. J. (2011). Theorizing Practice and Practicing Theory. Organization science, 22(5), 1240-1253.

Fernández Moya, M. (2010). A family-owned publishing multinational: The Salvat company (1869-1988). Business History, 52(3), 453-470.

File, K. M., \& Prince, R. A. (1996). Attributions for family business failure: the heir's perspective. Family Business Review, 9(2), 171-184.

Giovannoni, E., Maraghini, M. P., \& Riccaboni, A. (2011). Transmitting Knowledge Across Generations: The Role of Management Accounting Practices. Family Business Review, 24(2), 126-150.

González Ferrero, M., Guzmán Vásquez, A., \& Trujillo Dávila, M. A. (2010). The role of heirs in family businesses: The case of Carvajal. Innovar-Revista De Ciencias Administrativas $Y$ Sociales, 20(36), 49-65.

Grant, R. M. (1996). Toward a knowledge-based theory of the firm. Strategic Management Journal, 17(S2), 109-122.

Guo, C., \& Miller, J. K. (2010). Guanxi Dynamics and Entrepreneurial Firm Creation and Development in China. Management and Organization Review, 6(2), 267-291.

Haag, K. (2012). Rethinking family business succession: From a problem to solve to an ongoing practice. Jönköping International Business School,

Habbershon, T. G., \& Williams, M. L. (1999). A resource-based framework for assessing the strategic advantages of family firms. Family Business Review, 12(1), 1-25.

Hadjimichael, D., \& Tsoukas, H. (2019). Toward a Better Understanding of Tacit Knowledge in Organizations: Taking Stock and Moving Forward. Academy of Management Annals, 13(2), 672-703.

Hair, J. F., \& Sarstedt, M. (2014). Innovative and established research methods in family business: Description, illustration and application guidelines. Journal of Family Business Strategy, 5(1), 1-3.

Hall, A., \& Nordqvist, M. (2008). Professional management in family businesses: Toward an extended understanding. Family Business Review, 21(1), 51-69.

Hamilton, E. (2011). Entrepreneurial learning in family business: A situated learning perspective. Journal of Small Business and Enterprise Development, 18(1), 8-26.

Handler, W. C. (1990). Succession in family firms: a mutual role adjustment between entrepreneur and next- generation family members. Entrepreneurship: Theory and Practice, 15(1), 37-52. 
Handler, W. C. (1992). The Succession Experience of the Neaxt Generation. Family Business Review, 5(3), 283-307.

Hatak, I. R., \& Roessl, D. (2015). Relational Competence-Based Knowledge Transfer Within Intrafamily Succession. Family Business Review, 28(1), 10-25.

Heisig, P., \& Kannan, S. (2020). Knowledge management: does gender matter? A systematic review of literature. Journal of Knowledge Management, 24(6), 1315-1342.

Hjorth, D., \& Dawson, A. (2016). The burden of history in the family business organization. Organization Studies, 37(8), 1089-1111.

Holt, D. T., Pearson, A. W., Payne, G. T., Sharma, P., Tabor, W., Chrisman, J. J., . . . Vardaman, J. M. (2018). Nonfamily Members in Family Firms: A Review and Future Research Agenda. Family Business Review, 31(1), 54-79.

Jaskiewicz, P., Combs, J. G., \& Rau, S. B. (2015). Entrepreneurial legacy: Toward a theory of how some family firms nurture transgenerational entrepreneurship. Journal of Business Venturing, 30(1), 29-49.

Jaskiewicz, P., Combs, J. G., Shanine, K. K., \& Kacmar, K. M. (2017). Introducing the family: A review of family science with implications for management research. Academy of Management Annals, 11(1), 309-341.

Jaskiewicz, P., \& Dyer, W. G. (2017). Addressing the elephant in the room: Disentangling family heterogeneity to advance family business research. Family Business Review, $30(2), 111-118$.

Jaskiewicz, P., Uhlenbruck, K., Balkin, D. B., \& Reay, T. (2013). Is Nepotism Good or Bad? Types of Nepotism and Implications for Knowledge Management. Family Business Review, 26(2), 121-139.

Kallmuenzer, A., \& Scholl-Grissemann, U. (2017). Disentangling antecedents and performance effects of family SME innovation: A knowledge-based perspective. International Entrepreneurship and Management Journal, 13(4), 1117-1138.

Klenke, K. (2018). Knowledge Transfer through Leadership Succession in Intergenerational Family Firms. International Leadership Journal, 10(1), 3-36.

Konopaski, M., Jack, S., \& Hamilton, E. (2015). How family business members learn about continuity. Academy of Management Learning \& Education, 14(3), 347-364.

Koropp, C., Grichnik, D., \& Gygax, A. F. (2013). Succession financing in family firms. Small Business Economics, 41(2), 315-334.

Kotlar, J., \& De Massis, A. (2013). Goal Setting in Family Firms: Goal Diversity, Social Interactions, and Collective Commitment to Family-Centered Goals. Entrepreneurship Theory and Practice, 37(6), 1263-1288.

Kotlar, J., De Massis, A., Frattini, F., \& Kammerlander, N. (2020). Motivation Gaps and Implementation Traps: The Paradoxical and Time-Varying Effects of Family Ownership on Firm Absorptive Capacity. Journal of Product Innovation Management, 37(1), 2-25.

Le Breton-Miller, I., \& Miller, D. (2014). Temporal considerations in the study of family firms: Reflections on "the study of organizational behaviour in family business". European Journal of Work and Organizational Psychology, 23(5), 669-673.

Le Breton-Miller, I., Miller, D., \& Steier, L. P. (2004). Toward an Integrative Model of Effective FOB Succession. Entrepreneurship theory and practice., 28(4), 305-328.

Le Breton-Miller, I., \& Miller, D. (2015). The Arts and Family Business: Linking Family Business Resources and Performance to Industry Characteristics. Entrepreneurship Theory and Practice, 39(6), 1349-1370.

Letonja, M., \& Duh, M. (2016). Knowledge transfer in family businesses and its effects on the innovativeness of the next family generation. Knowledge Management Research \& Practice, 14(2), 213-224. 
Light, R. J., \& Pillemer, D. B. (1984). Summing up: the science of reviewing research. Cambridge,MA: Harvard University Press.

Lin, W. B. (2013). Research on knowledge sharing and interpersonal relationships: empirical study of family firms and non-family firms. Quality \& Quantity, 47(1), 151-166.

Lionzo, A., \& Rossignoli, F. (2013). Knowledge integration in family SMEs: an extension of the 4I model. Journal of Management \& Governance, 17(3), 583-608.

Long, R. G., \& Chrisman, J. J. (2014). Management succession in family business. In L. Melin, M. Nordqvist, \& P. Sharma (Eds.), SAGE handbook of family business (pp. 249-268). London: Sage.

Long, R. G., \& Mathews, K. M. (2011). Ethics in the family firm: Cohesion through reciprocity and exchange. Business Ethics Quarterly, 21(2), 287-308.

Lopes, C. M., Scavarda, A., Hofmeister, L. F., Tavares Thomé, A. M., \& Roehe Vaccaro, G. L. (2017). An analysis of the interplay between organizational sustainability, knowledge management, and open innovation. Journal of Cleaner Production, 142, 476-488.

March, J. G. (2005). Parochialism in the evolution of a research community: The case of organization studies. Management and Organization Review, 1(1), 5-22.

Martínez, A. B., Galván, R. S., \& Palacios, T. B. (2013). Study of Factors Influencing Knowledge Transfer in Family Firms. Intangible Capital, 9(4), 1216-1238.

Martínez, A. B., Galván, R. S., \& Palacios, T. M. B. (2016). An empirical study about knowledge transfer, entrepreneurial orientation and performance in family firms. European Journal of International Management, 10(5), 534-557.

Massingham, P. (2008). Measuring the impact of knowledge loss: more than ripples on a pond? Management Learning, 39(5), 541-560.

Mazzola, P., Marchisio, G., \& Astrachan, J. (2008). Strategic planning in family business: A powerful developmental tool for the next generation. Family Business Review, 21(3), 239-258.

McLarty, B. D., Vardaman, J. M., \& Barnett, T. (2019). Congruence in exchange: The influence of supervisors on employee performance in family firms. Entrepreneurship Theory and Practice, 43(2), 302-321.

McMullen, J. S., \& Warnick, B. J. (2015). To Nurture or Groom? The Parent-Founder Succession Dilemma. Entrepreneurship Theory and Practice, 39(6), 1379-1412.

Memili, E., Fang, H., \& Welsh, D. H. B. (2015). Value creation and value appropriation in innovation process in publicly-traded family firms. Management Decision, 53(9), 1921-1952.

Miller, D., Steier, L., \& Le Breton-Miller, I. (2003). Lost in time: intergenerational succession, change, and failure in family business. Journal of Business Venturing, 18(4), 513-531.

Miller, D., Steier, L., \& Le Breton-Miller, I. (2016). What Can Scholars of Entrepreneurship Learn from Sound Family Businesses? Entrepreneurship Theory and Practice, 40(3), 445-455.

Morgan, D. (1996). Family connections: An introduction to family studies (Vol. 45): Polity Press Cambridge.

Muskat, B., \& Zehrer, A. (2017). A power perspective on knowledge transfer in internal succession of small family businesses. Journal of Small Business \& Entrepreneurship, 29(5), 333-350.

Nahapiet, J., \& Ghoshal, S. (1998). Social Capital, Intellectual Capital, and the Organizational Advantage. The Academy of Management Review, 23(2), 242-266. 
Nason, R., Mazzelli, A., \& Carney, M. (2019). The Ties That Unbind: Socialization and Business-Owning Family Reference Point Shift. Academy of Management Review, 44(4), 846-870.

Nelson, R. R. (1982). An evolutionary theory of economic change. Cambridge, Mass.: Belknap Press of Harvard University Press.

Neubaum, D. O. (2018). Family business research: Roads travelled and the search for unworn paths. Family Business Review, 31(3), 257-270.

Nicholson, L., \& Rao-Graham, L. (2016). Knowledge Management Systems for Small Family-Owned Businesses-The Case of the English-speaking Caribbean. Social \& Economic Studies, 65, 133-159.

Nicolini, D. (2011). Practice as the site of knowing: Insights from the field of telemedicine. Organization science, 22(3), 602-620.

Nonaka, I. (1994). A Dynamic Theory of Organizational Knowledge Creation. Organization science, 5(1), 14-37.

Nonaka, I., \& Von Krogh, G. (2009). Tacit Knowledge and Knowledge Conversion: Controversy and Advancement in Organizational Knowledge Creation Theory. Organization science, 20(3), 635-652.

Nordqvist, M., Wennberg, K., \& Hellerstedt, K. (2013). An entrepreneurial process perspective on succession in family firms. Small Business Economics, 40(4), 10871122.

Oxford Economics. (2018). THE STATE OF THE NATION: The UK Family Business Sector 2017-18. Retrieved from https://www.oxfordeconomics.com/recentreleases/f060a8ac-a09d-4175-867e-fab8b368931a

Patel, P. C., \& Fiet, J. O. (2011). Knowledge Combination and the Potential Advantages of Family Firms in Searching for Opportunities. Entrepreneurship Theory and Practice, 35(6), 1179-1197.

Patriotta, G. (2020). Writing impactful review articles. Journal of Management Studies, 57(6), 1272-1276.

Pérez-Pérez, M., López-Férnandez, M. C., \& Obeso, M. (2019). Knowledge, renewal and flexibility: exploratory research in family firms. Administrative Sciences, 9(4), 87.

Perez, P. F., \& Puig, N. (2004). Knowledge and training in family firms of the European periphery: Spain in the eighteenth to twentieth centuries. Business History, 46(1), 7999.

Pipatanantakurn, K., \& Ractham, V. V. (2016). Knowledge Creation Aiding Family Business Succession Plan. International Journal of Business \& Management Science, 6(1), 6384.

Pittino, D., Barroso Martínez, A., Chirico, F., \& Galvan, R. S. (2018). Psychological ownership, knowledge sharing and entrepreneurial orientation in family firms: The moderating role of governance heterogeneity. Journal of Business Research, 84, 312326.

Pogutz, S., \& Winn, M. I. (2016). Cultivating Ecological Knowledge for Corporate Sustainability: Barilla's Innovative Approach to Sustainable Farming. Business Strategy and the Environment, 25(6), 435-448.

Polanyi, M. (2015). Personal knowledge: towards a post-critical philosophy: University of Chicago Press.

Reay, T. (2019). Family routines and next-generation engagement in family firms. Entrepreneurship Theory and Practice, 43(2), 244-250.

Roscoe, M. T., Vieira, A., \& Grzybovski, D. (2015). Family social capital, transgenerational learning and transgenerational entrepreneurship. In P. Sharma, N. Auletta, R.-L. DeWitt, M. José Parada, \& M. Yusof (Eds.), Developing Next Generation Leaders for 
Transgenerational Entrepreneurial Family Enterprises (pp. 192-211): Edward Elgar Publishing.

Schatzki, T. R. (1996). Social practices: A Wittgensteinian approach to human activity and the social: Cambridge University Press.

Serrano-Bedia, A. M., Lopez-Fernandez, M. C., \& Garcia-Piqueres, G. (2016). Analysis of the relationship between sources of knowledge and innovation performance in family firms. Innovation-Organization \& Management, 18(4), 489-512.

Sharma, P., \& Chua, J. (2013). Asian family enterprises and family business research. Asia Pacific Journal of Management, 30(3), 641-656.

Sharma, P., Salvato, C., \& Reay, T. (2014). Temporal Dimensions of Family Enterprise Research. Family Business Review, 27, 10-19.

Spender, J. C., \& Grant, R. M. (1996). Knowledge and the firm: Overview. Strategic Management Journal, 17(S2), 5-9.

Steier, L. (2001). Next-generation entrepreneurs and succession: An exploratory study of modes and means of managing social capital. Family Business Review, 14(3), 259276.

Su, E., \& Carney, M. (2013). Can China's family firms create intellectual capital? Asia Pacific Journal of Management, 30(3), 657-675.

Su, E., \& Dou, J. S. (2013). How Does Knowledge Sharing Among Advisors From Different Disciplines Affect the Quality of the Services Provided to the Family Business Client? An Investigation From the Family Business Advisor's Perspective. Family Business Review, 26(3), 256-270.

Szulanski, G. (1996). Exploring Internal Stickiness: Impediments To The Transfer Of Best Practice Within The Firm. Strategic Management Journal, 17(27).

Szulanski, G. (2000). The process of knowledge transfer: A diachronic analysis of stickiness. Organizational Behavior and Human Decision Processes, 82(1), 9-27.

Szulanski, G., Ringov, D., \& Jensen, R. J. (2016). Overcoming stickiness: How the timing of knowledge transfer methods affects transfer difficulty. Organization science, 27(2), 304-322.

Tranfield, D., Denyer, D., \& Smart, P. (2003). Towards a methodology for developing evidence-informed management knowledge by means of systematic review. British Journal of Management, 14(3), 207-222.

Tsoukas, H., \& Vladimirou, E. (2001). What is Organizational Knowledge? Journal of Management Studies, 38(7), 973-993.

Utrilla, P. N. C., \& Torraleja, F. A. G. (2013). The importance of mentoring and coaching for family businesses. Journal of Management \& Organization, 19(4), 386-404.

Wang, X. T., \& Jiang, M. S. (2018). Learning alongside and learning apart: successor nurturing styles in family business succession. Knowledge Management Research \& Practice, 16(2), 258-266.

Wang, Y. Z., Lo, F. Y., \& Weng, S. M. (2019). Family businesses successors knowledge and willingness on sustainable innovation: The moderating role of leader's approval. Journal of Innovation \& Knowledge, 4(3), 188-195.

Wasim, J., Cunningham, J., Maxwell-Cole, A., \& Taylor, J. R. (2018). Nonfamily knowledge during family business succession: a cultural understanding. International Journal of Entrepreneurial Behavior \& Research, 26(1), 141-157.

Winter, M., Fitzgerald, M. A., Heck, R. K., Haynes, G. W., \& Danes, S. M. (1998). Revisiting the study of family businesses: Methodological challenges, dilemmas, and alternative approaches. Family Business Review, 11(3), 239-252. 
Woodfield, P. J., \& Husted, K. (2017). Intergenerational knowledge sharing in family firms: Case-based evidence from the New Zealand wine industry. Journal of Family Business Strategy, 8(1), 57-69.

Woodfield, P. J., \& Husted, K. (2019). How does knowledge sharing across generations impact innovation? International Journal of Innovation Management, 23(8), 1940004.

Wu, C. H. (2013). Family ties, board compensation and firm performance. Journal of Multinational Financial Management, 23(4), 255-271.

Yew, J. L. K., \& Gomez, E. T. (2014). Advancing tacit knowledge: Malaysian family SMEs in manufacturing. Asian Economic Papers, 13(2), 1-24.

Zahra, S. A., \& Filatotchev, I. (2004). Governance of the entrepreneurial threshold firm: a knowledge-based perspective. Journal of Management Studies, 41(5), 885-897.

Zahra, S. A., Neubaum, D. O., \& Larraneta, B. (2007). Knowledge sharing and technological capabilities: The moderating role of family involvement. Journal of Business Research, 60(10), 1070-1079. 
Figure 1. Cumulative number of articles published by year

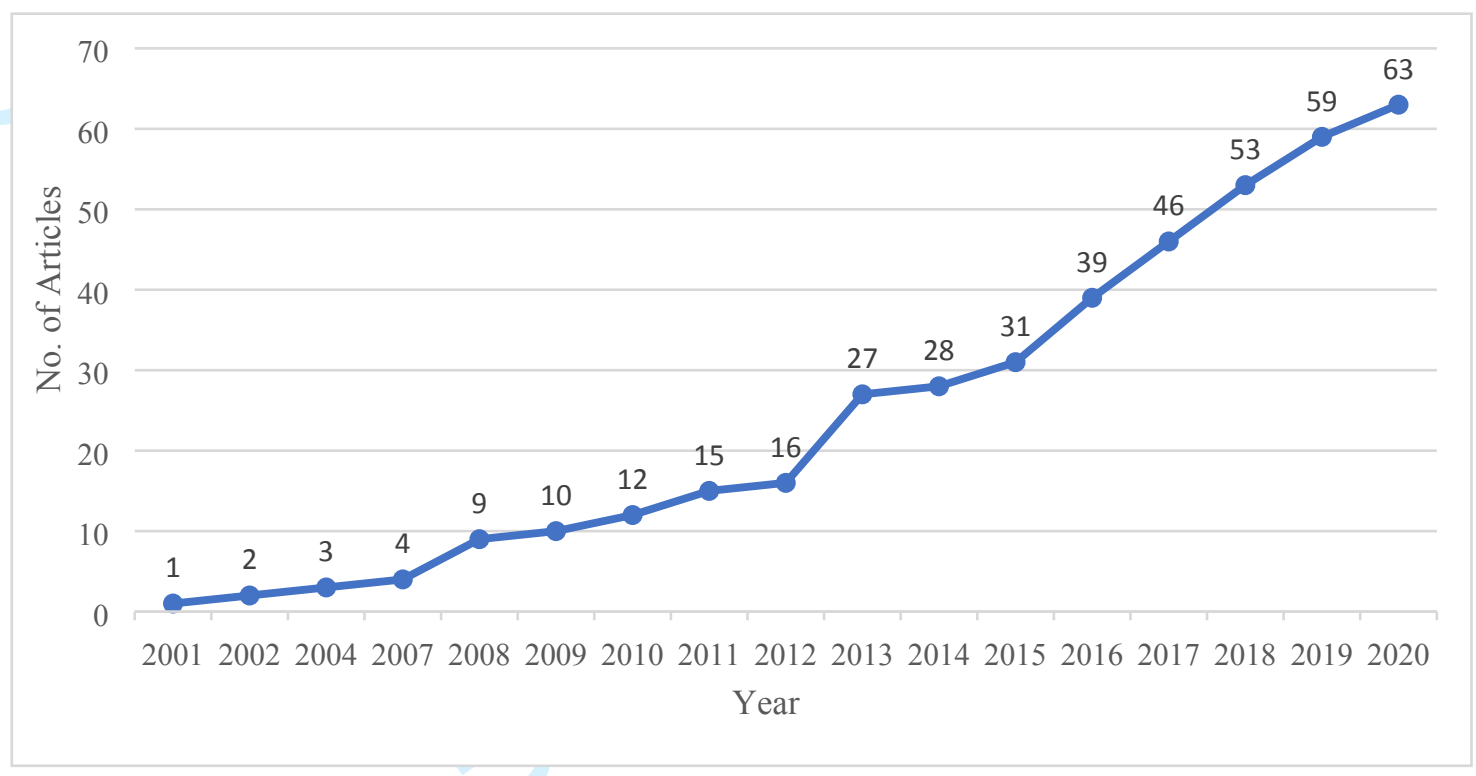


Figure 2. Descriptive map of regions (empirical papers only)

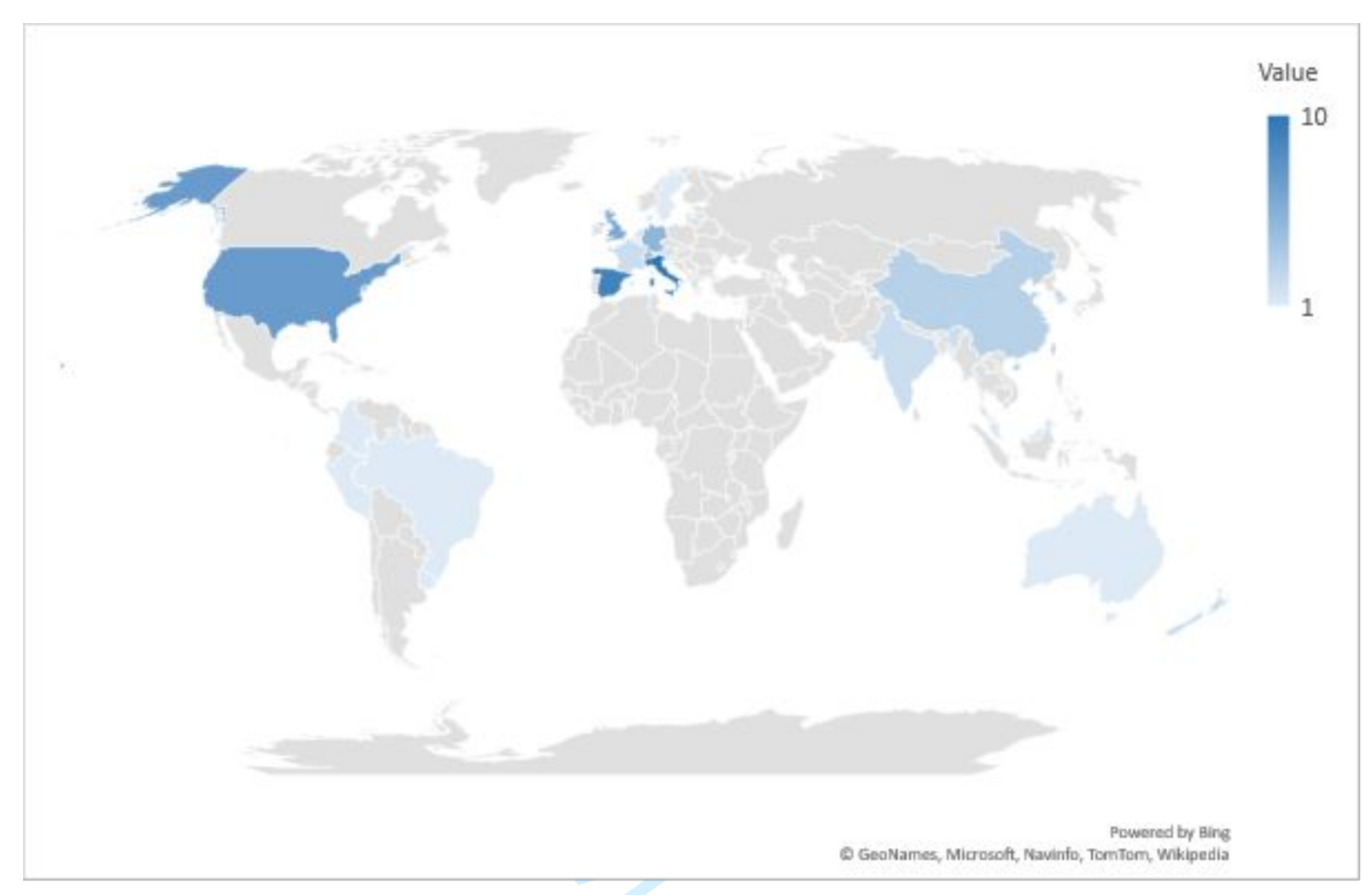

30

31

32

33

34

35

36

37

38

39 
Table 1. Systematic literature review procedure

\begin{tabular}{|c|c|c|c|c|}
\hline & Description & $\begin{array}{l}\text { Web of } \\
\text { Science }\end{array}$ & EBSCO & Total \\
\hline \multirow[t]{2}{*}{ Step 1} & Articles with selected keywords & 292 & 240 & 532 \\
\hline & $\begin{array}{l}\text { After merging the results from the different databases and } \\
\text { deleting duplicate articles }\end{array}$ & & & 457 \\
\hline Step 2 & $\begin{array}{l}\text { After reading the titles and abstracts, eliminating the non- } \\
\text { relevant articles }\end{array}$ & & & 80 \\
\hline \multirow[t]{2}{*}{ Step 3} & $\begin{array}{l}\text { After reading the full articles and eliminating the non-relevant } \\
\text { articles }\end{array}$ & & & 63 \\
\hline & Final sample & & & 63 \\
\hline
\end{tabular}

Search criteria for Web of Science: Date Range: All years (1900 - 2020) (Maximum range available for this database). Citation Databases: Science Citation Index Expanded (SCI-Expanded) 1900-present; Social Sciences Citation Index (SSCI) 1990-present; Arts \& Humanities Citation Index (A\&HCI) 1975-present. Document Type (Article). Language (English). Web of Science Categories (Anthropology; Business; Management; Cultural Studies; Economics; Reginal Urban Planning; URBAN STUDIES; Psychology Applied; Humanity Interdisciplinary; History of Social Science; Sociology; Area Studies; Educational Education Research; Psychology Social; Political Science; Family Studies; Psychology Multidisciplinary; Social Sciences Interdisciplinary; Education Scientific Disciplines; Ethnics Studies; History; International Relations; Social Issues; Communication; Business Finance). Search strings: in topic.

Search criteria for EBSCO: Search Modes (Boolean/Phrase). Apply related words. Only Scholarly (Peer reviewed) Journals. Language (English). Document Type (Journal Article). Geographic Region (All). Publication Status: Fully published. Database: Business Source Complete, EconLit, APA PsycArticles, SocINDEX with Full Text. 
Table 2. Journals that published more than one article

\begin{tabular}{lr}
\hline Journal & Number of articles \\
\hline Family Business Review & 10 \\
Knowledge Management Research \& Practice & 6 \\
Journal of Family Business Strategy & 4 \\
Journal of Knowledge Management & 3 \\
Business History & 2 \\
Entrepreneurship Theory and Practice & 2 \\
International Journal of Business \& Management Science & 2 \\
Journal of Business Research & 2 \\
Journal of Small Business \& Entrepreneurship & 2 \\
\hline
\end{tabular}


Table 3. Descriptive data on articles by methodology adopted

\begin{tabular}{lcr}
\hline Methodology Adopted & Number of articles \\
\hline Theoretical/Conceptual & Qualitative & 13 \\
\hline & Quantitative & 26 \\
Empirical & Mixed & 21 \\
& & 3 \\
Total no. for empirical papers & 50 \\
\hline Total & $\mathbf{6 3}$ \\
\hline
\end{tabular}


Table 4. Findings of the literature review

\begin{tabular}{|c|c|c|c|c|}
\hline & & \multicolumn{3}{|c|}{ Phases of Succession } \\
\hline & & $\begin{array}{c}\text { Phase } 1 \\
\text { Setting the rules }\end{array}$ & $\begin{array}{c}\text { Phase } 2 \\
\text { Grooming the successor }\end{array}$ & $\begin{array}{c}\text { Phase } 3 \\
\text { Passing the baton } \\
\end{array}$ \\
\hline \multirow{3}{*}{ 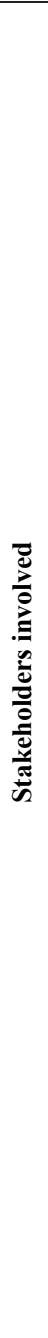 } & $\begin{array}{l}\text { Between } \\
\text { incumbent and } \\
\text { successor }\end{array}$ & $\begin{array}{l}\text { - Relational competence } \\
\text { - Idiosyncratic knowledge } \\
\text { - Private versus specific knowledge management } \\
\text { - Knowledge integration process }\end{array}$ & $\begin{array}{l}\text { - Commitment and psychological ownership } \\
\text { - Engaging in training courses } \\
\text { - Gaining experience outside the family business or from } \\
\text { non-family members } \\
\text { - Business culture } \\
\text { - Linkages with Family Business Associations } \\
\text { - Power relationships and trust } \\
\text { - Nurturing style: "learning alongside" versus "learning } \\
\text { apart" } \\
\text { - Transfer of moral values and competence values }\end{array}$ & $\begin{array}{l}\text { - Knowledge reservoirs } \\
\text { - Motivation gap versus implementation gap between } \\
\text { generations } \\
\text { - External knowledge } \\
\text { - Constraint of incumbent's approval }\end{array}$ \\
\hline & $\begin{array}{l}\text { Within } \\
\text { the family } \\
\text { boundary }\end{array}$ & $\begin{array}{l}\text { - Leadership styles (e.g. participative, paternalistic) } \\
\text { - Set-up of knowledge management systems }\end{array}$ & $\begin{array}{l}\text { - Familiness } \\
\text { - Family members are "knowledge supervisors" } \\
\text { - Multiple generations involved } \\
\text { - Number of family members in the TMT } \\
\text { - Family ties }\end{array}$ & $\begin{array}{l}\text { - Development of knowledge integration as dynamic } \\
\text { capabilitties } \\
\text { - Previous experiences } \\
\text { - Accumulation of explicit knowledge and its conversion } \\
\text { into tacit knowledge } \\
\text { - Internalization of knowledge } \\
\text { - Psychological ownership } \\
\text { - Social capital } \\
\text { - Relationship conflict } \\
\text { - Generation in control } \\
\text { - Generational involvement and family involvement in the } \\
\text { TMT } \\
\text { - Long-term orientation }\end{array}$ \\
\hline & $\begin{array}{l}\text { Across } \\
\text { the family } \\
\text { boundary }\end{array}$ & $\begin{array}{l}\text { - Simultaneous set-up of ways to transfer structural, social, } \\
\text { and human capital } \\
\text { - Measurement of intellectual capital } \\
\text { - Set-up of management accounting systems } \\
\text { - Sharing of knowledge among external advisors } \\
\text { - Family wisdom }\end{array}$ & $\begin{array}{l}\text { - Socialization of next generation members } \\
\text { - Combination of experiential knowledge assets (know- } \\
\text { how) and knowledge from serving multiple roles (e.g., } \\
\text { managers and owners) } \\
\text { - Training inside and outside the family business } \\
\text { - Training practices changing over time }\end{array}$ & $\begin{array}{l}\text { - Access to external sources of knowledge (including } \\
\text { specific knowledge, e.g. sustainability or finance) } \\
\text { - Development of knowledge management process } \\
\text { capabilities } \\
\text { - Networking and social capital } \\
\text { - Internationalization } \\
\text { - Survival across historical critical events (e.g., economic } \\
\text { crises or wars) } \\
\text { - Open innovation approach } \\
\text { - Imprinting and fraternization as dynamic capabilities } \\
\text { - Leveraging on technological opportunities and inter- } \\
\text { - organizational collaboration } \\
\text { - Experience with debt suppliers } \\
\text { - Owner-managers' financial attitudes toward debt } \\
\text { - Presence of non-family members }\end{array}$ \\
\hline
\end{tabular}

